\title{
A natural life: neo-rurals and the power of everyday practices in protected areas
}

\author{
Jose A. Cortes-Vazquez ${ }^{1}$ \\ University of Manchester, UK
}

\begin{abstract}
The worldwide expansion of nature conservation initiatives has attracted a great deal of attention among political ecologists. Concerned about the effects on people and the environment, critical scholars have attempted to identify the drivers of conservation, and how power operates. Conservation policies, practices and conflicts have generated a large literature about the role of states, expert bureaucracies, private corporations, NGOs and technologies of government. In this article I aim to extend this literature by paying attention to a largely neglected field of power relations, defined by the efforts made by new inhabitants of natural protected areas, who have moved to these new locations and have strived to construct and maintain an idyll wherein they can enjoy a new, 'natural life.' Using Bourdieu's notions of cultural capital and habitus, I demonstrate that, in certain places, it is in the everyday practices of making a natural protected area a new home where power relations unfold more subtly, although no less intensely. I illustrate this empirically with a particular case study: the Cabo de Gata-Níjar Natural Park in southeastern Spain. I examine the role played by neo-rurals in the establishment of this protected area, present an ethnographic account of their everyday practices, and link them to the conflicts that have emerged with other social groups, with whom they compete for the right to use and access local resources.
\end{abstract}

Key words: Conservation, political ecology, protected areas, neo-rurals, power, Europe

\section{Résumé}

L'expansion mondiale des initiatives de conservation de la nature a attiré beaucoup d'attention chez les écologistes politiques. Préoccupée par les effets sur les personnes et l'environnement, les chercheurs critiques ont tenté d'identifier la façon dont le pouvoir fonctionne dans la conservation. Il y a maintenant pluiseurs ouvrages sur la politique, les pratiques et les conflits sur la conservation de la nature, avec un accent sur le rôle de l'état, des bureaucraties d'experts, des entreprises privées, des ONG et des technologies de gouvernement. Dans cet article, je fais attention à un domaine largement négligé: les relations de pouvoir entourant les efforts déployés par les nouveaux habitants de zones naturelles protégées, qui ont déménagé dans ces nouveaux lieux et se sont efforcés de construire et d'entretenir une idylle dans laquelle ils peuvent profiter d'une nouvelle «vie naturelle». Les notions de Bourdieu, le capital culturel et habitus, sont utiles, afin de démontrer qu'au cours des pratiques quotidiennes de fonder un nouveau foyer dans une zone naturelle protégée, où les relations de pouvoir se dérouler de façon plus subtile, mais non moins intense. J'illustre cela avec une étude de cas: le parc naturel de Cabo de Gata-Nijar dans la région sud-est de l'Espagne. Je examine le rôle joué par les néo-ruraux dans l'établissement de cette zone protégée, et je présente un compte rendu ethnographique de leurs pratiques quotidiennes. Ces pratiques sont liées aux conflits qui ont émergé avec d'autres groupes sociaux, avec lesquels ils sont en concurrence pour le droit d'utiliser et accéder aux ressources locales.

Mots clés: Conservation, écologie politique, les aires protégées, néo-ruraux, le pouvoir, l'Europe

\footnotetext{
${ }^{1}$ Dr. Jose Cortes-Vazquez, Marie Curie postdoctoral research fellow, Institute of Development Policy and Management, University of Manchester, UK. Email: joseantonio.cortesvazquez "at" manchester.ac.uk. This research was carried out thanks to a Research Incentivisation Scheme grant from the School of Geography and Archaeology, National University of Ireland Galway (Republic of Ireland), where the author was lecturing when an early version of this article was first submitted. I would like to thank the colleagues at NUIG for all the support I received while carrying out this research. I am also grateful to the four anonymous reviewers that provided very insightful comments on an earlier version of this article.
} 


\section{Resumen}

La velocidad con la que las políticas de conservación se han expandido a lo largo y ancho del planeta en épocas recientes ha atraído poderosamente la atención de aquellos que desarrollan su trabajo dentro de la ecología política. Preocupados por el impacto de estas políticas sobre las poblaciones locales y los ecosistemas, numerosos autores se han esforzado por desenmascarar las relaciones de poder y el papel jugado por determinados actores clave, como son el estado, los mercados, las tecnologías de gobierno, los procedimientos burocráticos y las ONGs medioambientalistas. Mi intención en este artículo es contribuir al estudio de las relaciones de poder en las políticas de conservación mediante el análisis de un campo por ahora bastante inexplorado: el de las prácticas cotidianas y los estilos de vida de aquellos que cambian su lugar de residencia habitual y se mudan a espacios naturales protegidos en busca de una vida alternativa dentro de lo que para ellos es un ambiente idílico. Mi estudio se centra en un caso concreto: el Parque Natural Cabo de Gata-Níjar, en el sureste del estado español. En estas páginas muestro el papel que la población neorrural ha jugado en la declaración de este espacio como protegido, analizo etnográficamente sus estilos de vida y prácticas cotidianas y exploro, haciendo uso de las nociones de capital cultural y habitus de Bourdieu, la relación que existe entre estos estilos de vida y estas prácticas cotidianas con los conflictos que han surgido en este espacio desde la introducción de políticas de conservación.

Palabras clave: Conservación, ecología política, espacios protegidos, neorrurales, poder, Europa

\section{Introduction}

The worldwide expansion of nature conservation initiatives has attracted a great deal of attention among political ecologists. Concerned about the effects on people and the environment, critical scholars have attempted to identify drivers and the operation of power in conservation initiatives. Popular themes include issues of land ownership, resource access, the role of states, environmental NGOs (ENGOs), the private sector and hegemonic understandings of nature (Adams and Hutton 2007). These studies have permitted political ecologists to demonstrate that, for better or worse, conservation is a form of environmental control (Peet et al. 2010).

Critical studies of conservation conflicts in natural protected areas (NPAs) have proven particularly insightful. They have showed how conservation initiatives have become a powerful instrument that re-shapes and reorganizes the world in accordance to certain interests and environmental views (Brockington and Duffy 2010; West et al. 2006). They have also shown that the introduction of conservation measures in NPAs is disproportionate, meaning fortune and misfortune is unevenly spread, usually to the disadvantage of poor individuals and groups (Brockington et al. 2008). With the analysis of changes in land use, restrictions to certain economic activities and even the physical eviction of local inhabitants, these critical studies have unearthed multiple procedures, instruments and technologies of government through which control is exerted in NPAs (Agrawal 2005; Anderson and Berglund 2003; Arsel and Büscher 2012; Chatty and Colchester 2002; Fairhead and Leach 2003; Igoe 2004).

Despite the detailed level of analysis achieved in these studies, a clear and unproblematic definition of the form and ways that power operates in conservation has proved elusive (Escobar 1996; Robbins 2004; for a recent review see Holmes 2009). In this article I challenge and extend the common focus on the actions of states, expert bureaucracies, private corporations, NGOs and intimate technologies of government. I seek to complement the arguments produced about all these different actors by paying attention to the multiplicity of force relations that manifest in the everyday practices and lifestyles of people living in protected areas. As such, I engage with Foucault's (2003) goal of "cutting off the King's head" and present a "beheaded" political ecology of nature conservation (Agrawal 2005; Fletcher 2010). I use a slightly different focus to the Foucauldian tradition of studying the politics, institutions, discourses and technologies that inspire the "conduct of conduct" and that seek the subjugation of individuals to conservation goals. Instead I center my attention on a largely neglected field of power relations, defined by the efforts made by new inhabitants of natural protected areas, who have moved to these new locations and have striven to construct and maintain an idyll wherein they can enjoy a new, 'natural life.' Using Bourdieu's concepts of cultural capital and habitus (1977, 1979), I go on to demonstrate that, in certain places, it is in the everyday struggles to make a NPA a new home where relations of force unfold; more subtly although no less intensely.

I illustrate these ideas empirically with a case study: the Cabo de Gata-Níjar Natural Park in 
southeastern Spain (Figure 1). I examine the role that, over the recent decades, the growing population of pro-rural migrants has played in the establishment of this natural park. I then present an ethnographic account of their daily experiences and the strategies that they have brought into play in order to produce a new place to live in. I approach these strategies as the manifestations of a neo-rural form of habitus and link them to the conflicts that have emerged with other local social groups, with whom they compete for the preferential right to use and access the resources in their surrounding environment. ${ }^{2}$ My intention is to demonstrate that in addition to the institutions, agents and apparatuses that control and rule the natural park, we also need to pay attention to the different actions orchestrated by neo-rurals in the construction of an idyllic place. I suggest that in those actions we can observe the workings of a subtle kind of power through which neo-rurals aim to exert their right to use and appropriate the surrounding resources ${ }^{3}$ over the local inhabitants.
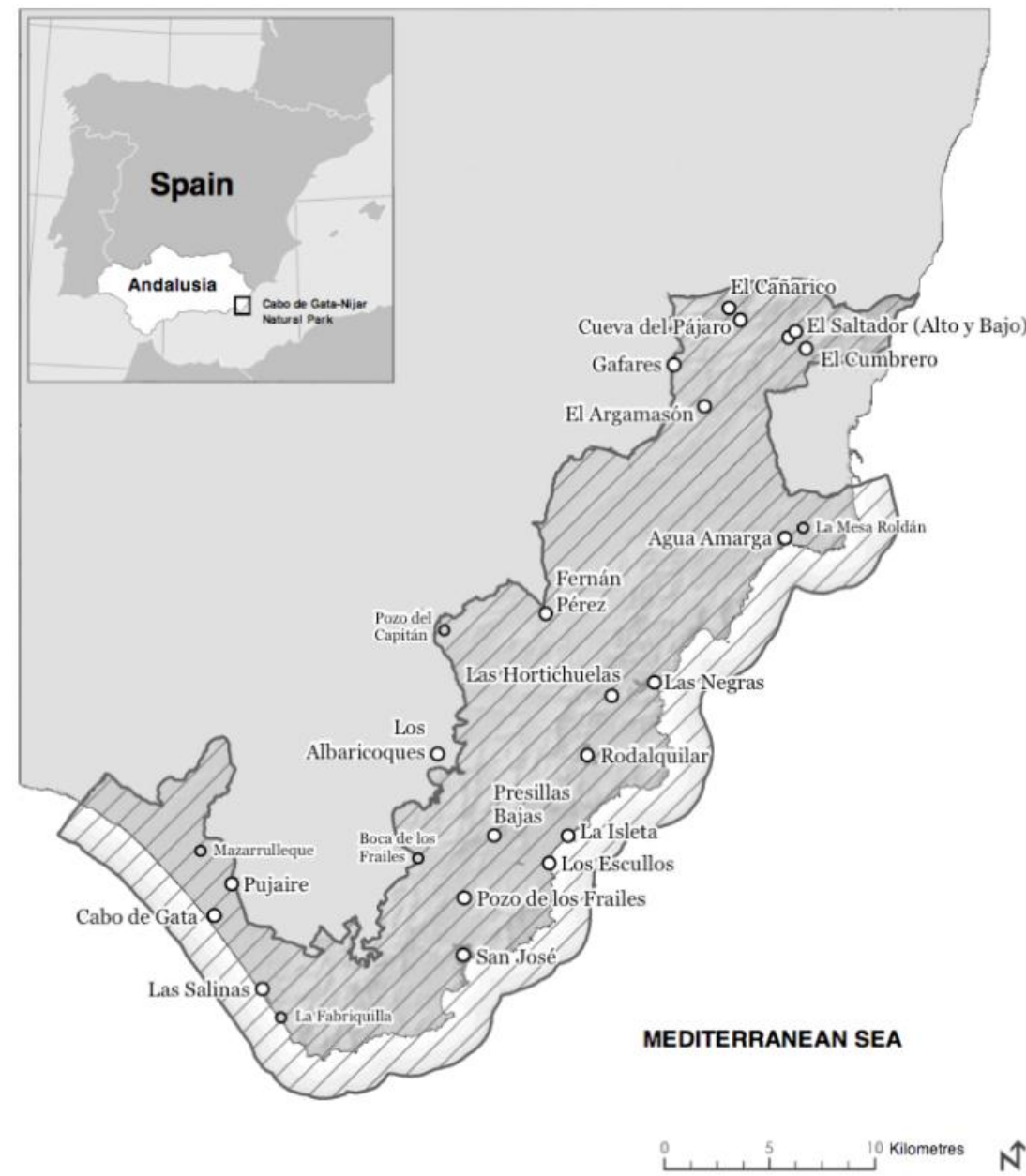

Figure 1: The Cabo de Gata-Níjar Natural Park.

\footnotetext{
2 I understand the term habitus in Bourdieu's terms $(1977,1979)$ as classified and classifying practices that result from the embodiment of cultural capital.

${ }^{3}$ A cautionary note is needed here. In what follows I will be referring to the expansion of conservation initiatives informed by so-called Western, modern environmentalism (Pepper 1996) and supported by international institutions like the World Bank, global environmental NGOs and rich, northern countries in Europe and North America. Although I acknowledge the importance and diversity of other forms of environmentalism and other grassroots and communitybased conservation initiatives (Berkes 2009; Guha 2000; Guha and Martinez-Alier 1997), in this article I am mostly interested in Western forms of conservation and the power relations upon which their expansion rely. The reasons are exclusively strategic: the geographical adscription of the neo-rural movement, largely formed by Western and educated ex-urbanites, force us to examine their role in the expansion of conservation initiatives within the ontological, epistemological and political boundaries of modern environmentalism.
} 
The contribution that this study makes to the political ecology of conservation is theoretical and practical. Firstly, I suggest that when we examine the drivers of conservation in certain geographical contexts such as NPAs in Europe, it is critical that we acknowledge the support given by neo-rural groups. There is a large consensus about the key role that these groups have played in the deep changes experienced in rural areas in Europe (Figueiredo 2008; Halfacree 2013; Mahon et al. 2012; Nogue 1988, Silva and Figueiredo 2013). Despite this, pro-rural migrants have rarely been the focus of attention in critical studies of conservation. Part of the reason for such indifference rests on the fact that neo-rurals have frequently been excluded from 'local populations' as many scholars reserve this tag strategically for those social groups selfproclaimed as 'the locals' (Cortes-Vazquez 2012; Valcuende et al. 2011). Querying the role of these migrants in the politics of NPA governance, as I do here, challenges and extends current ideas of power in the political ecology of nature conservation. This leaves the following questions open to future research: is this neo-rural element important enough to motivate the identification of a conservation model that is particular to those protected areas with a long and noteworthy story of neo-rural influence? And what would be the theoretical, conceptual and methodological implications of such conservation model?

Secondly, most of the critical writings concerned with the impacts of conservation initiatives urge experts and policy makers with responsibility for the management of NPAs to change their attitudes, perceptions, ideas and procedures (Brockington et al. 2008; Vaccaro et al. 2013). However, if power is also exerted through subtle force relations in everyday practices, it would seem that the recommendations found in critical studies fall short in their attempt to attribute responsibilities for the negative impact of conservation. As such, it would be equally important to explore further if a change of attitudes among neorurals is also essential to conservation strategies that comply with the principles of social justice.

In what follows I will develop the key ideas, concepts and concerns outlined in this introduction and explain how they originated and influenced the structure of my analysis. I will then present the story of conservation in Cabo de Gata, while paying particular attention to the expectations of those who relocated to this area in search of a new life. I will then describe the different strategies that these people have followed in recent decades with the aim of making this natural park a new home. Next I will link these strategies to the several conflicts that have emerged in the last few decades. Finally, I will summarize the implications of this particular way of 'beheading' the idea of power in the political ecology of conservation, moving from the role of institutions to the everyday interactions between people with different interests and lifestyles.

\section{Parks, people and power}

\section{The origins}

The idea of this article originated during a short trip to the Cabo de Gata-Níjar Natural Park in December 2013. It was my first visit since I completed my PhD within this NPA, two and half years before, which focused on conservation conflicts between local farmers, shepherds, fishermen, park officials, urban developers and ENGOs. The trip was to leave a lasting impression on my ideas about power and force relations in conservation, not because of new developments in the aforementioned conflicts, but due to a local art event I attended with friends.

During my visit a good friend of mine, who is originally from the city of Barcelona, but has been a Park resident for the last fifteen years, invited me to see a play her child was performing in. The event was taking place in the community house in Rodalquilar, an ex-mining village located right at the geographical center of the Natural Park, which today hosts the park office and directorate and symbolizes the core of conservation politics. Children of all ages from Rodalquilar and nearby villages were taking part in the play a staging of Alice in Wonderland - and although none of them were English native speakers, the play was being performed in English. Most of the children performing were of parents who, like my friend, had moved to Cabo de Gata in the last few decades, coming from urban areas either in Spain or in other countries in Europe. Notably absent were the children of those parents who had been born and raised in the area.

On first reflection I felt this moment to be indicative of the conflicts between native and non-native regarding land and resource access that have emerged in the Natural Park over the past three decades following the introduction of conservation policies. These conflicts have generated a highly polarized society 
in Cabo de Gata with groups that hold radically opposed views on nature conservation (see more in Valcuende et al. 2011; Cortes-Vazquez 2012): those who moved to the region in recent years, leaving urban areas in the search of a new, alternative life within a natural and well-preserved place and those native inhabitants (mostly farmers, shepherds, fishermen and landowners) whose livelihoods and historic ways of working were jeopardized and notably transformed by the establishment of the natural park.

The absence of native inhabitants both as audience members and taking part in the event could be a reflection of this social division; a clear manifestation of the extent that disagreements over resource access pervade any act of socialization. But then I started to suspect that there could be more to this than passive reflection of underlying tensions. Seduced by poststructuralist ideas of lifestyle, distinction and discipline, I asked myself: could this kind of event, certainly at odds with the customary type of social events in rural areas in southern Spain (Moreno-Navarro 1996), be somehow accountable for the gap between these two social groups? Was this expression of a characteristic cosmopolitan ethos among new residents somehow related to issues of people-Park conflicts? In other words, could events like this theatre play in English create, consolidate or even widen social divisions in Cabo de Gata?

\section{A beheaded political ecology of nature conservation}

The questions that emerged, while attending this art event, alluded to a barely explored field in the political ecology of conservation, which motivated me to do this research. I have long been aware that exploring whether social events could account for social divisions in this natural park would force us to sharpen our knowledge of the forms and ways that power operates in conservation. The magnitude of the challenge becomes evident in light of the historical evolution of ideas of power in political ecology.

As mentioned in the introduction, conceptualizing power has been one of the most problematic aspects of the field. The early urge to integrate land use practices with local-global political economy and with a growing politicization of the environment (e.g. Blaikie and Brookfield 1987; Bryant 1992) was later questioned for approaching nature as a passive background of social action (Robbins 2004: 52). This questioning gave rise to social constructivist approaches, treating discourses as having powerful effects, and seeing environmental representations as social facts (Escobar 1996). The post-structural turn in political ecology fostered the questioning of systems of truth in institutional and expert discourses (Escobar 1999; Ferguson 1990; Zimmerer 1996). It also provoked a more general interrogation of the relations between different environmental discourses and power (see for example Escobar 2000; Fairhead and Leach 1996; Gray 2002; Mackenzie 2006; Mels 2002; Sletto 2002).

Ideas of how humans use and appropriate natural resources have an important bearing on conservation initiatives (Adams and Hutton 2007). A thorough review of the diversity of geographies, conservation models, key actors, interests, discourses and technologies of government exceeds the scope of this article but a brief account is provided below. ${ }^{4}$ Studies of conservation in African cases (e.g. Tanzania, South Africa, Namibia, Kenya and Madagascar) have stressed the role of colonial forces and their attempts to re-organize colonized lands under certain ideas of modernity and development and in accordance to their own colonial interests (Adams 2004). In recent decades, international NGOs, celebrities, international institutions like the World Bank and private corporations have replaced the old colonial agents as the key outside actors behind conservation efforts (Brockington 2014; Duffy 2008).

Although present in these studies (see for example Corson 2011 on Madagascar), the role of the state in conservation has been most thoroughly discussed in relation to Latin American (e.g. Holmes 2014 on the Dominican Republic), Asian (e.g. Peluso 1995 on Indonesia) and European contexts (e.g. Vaccaro 2005 and Vaccaro and Beltran 2008 on Spain; Mels 2002 on Sweden). Conservation initiatives, and more particularly protected areas, have been approached as examples of territorialization, through which states seek control over land and social groups (Peluso and Lund 2011). States have found many different ways to channel their interests and to exert their power, including the use of violence in cases of forced eviction from conservationtargeted areas in the most extreme instances of fortress conservation (Igoe 2004), direct physical and

\footnotetext{
${ }^{4}$ Diverse reviews can be found in the work of Adams (2004), Agrawal and Gibson (1999), Anderson and Berglund (2003), Brockington et al. (2008), Brockington and Duffy (2010), Büscher et al. (2012), Chatty and Colchester (2002), Igoe (2004), Vaccaro et al. (2013) and West et al. (2006).
} 
economic coercion in the more common 'fences-and-fines' model (Cortes-Vazquez 2012), and diverse technologies of government in community-based and neoliberal initiatives (Agrawal 2005; Fletcher 2010; Ruiz-Ballesteros 2009).

States, NGOs, transnational institutions and private actors have also found hegemonic ideas of nature to be strategic allies. They have promoted and justified conservation initiatives by arguing nature is important to national identity (Cronon 1995) or part of the green economy (Igoe et al. 2010). In recent years the neoliberal turn in conservation is making critical scholars pay growing attention to different conservation strategies nurtured by global capital, illustrating issues of primitive accumulation, uneven development, commoditization and land grabbing (Apostodopoulou and Adams 2014; Büscher et al. 2012; Corson 2011; Neves and Igoe 2012; Sullivan 2006, 2013).

In short, discussions about who exerts power, and how, have been central to studies on conservation and natural protected areas. Vaccaro et al. (2013) summarize the above in terms of three main actors: state, market and culture. They propose that, despite the form adopted by conservation initiatives (state integration, state-making projects, colonization, resource use rationalization, national identity formation, heritagization, commoditization, outsourcing, and taste changes), all of them largely rely on the coercive force of the state, the sway of economic incentives and deterrents, and the imposition of hegemonic environmental views. Where can we locate within this framework the actions taken by pro-rural migrants moving into protected areas and working towards the construction and defense of a natural idyll?

I believe that the answer to this question lies on a detailed and clearer understanding of their role in environmental governance in NPAs. There is a relative lack of attention paid to European cases in the Anglophone literature on conservation (Redford 2011), but it is in Europe where issues of pro-rural migrations in protected areas have been more frequent (Silva and Figueredo 2013). There are some instances in other locations in Latin America (Vaschetto 2006) and elsewhere (Cadieux and Hurley 2009). To study them we need an alternative approach, that differs from the Marxian tradition of focusing on the role of states and capital (see for example Apostodopoulou and Adams 2014; Neves and Igoe 2012). It must address the subtle forms in which governmentality and the 'conduct of conduct' operate (Rose 1999, see for example Escobar 1998); and the use of Gramscian frames to study the impact of hegemonic ideologies (e.g. Igoe et al. 2010). I suggest that a Bourdieusian approach that takes into account the role of cultural capital and habitus in spatial and social re-arrangements can help us understand the influence exerted in conservation by the everyday practices carried out by neo-rurals towards the production, defense and shaping of a natural idyll in which to live. As such, it would be an alternative form of approaching a beheaded political ecology of conservation, one where the embodiment of cultural capital in the form of different lifestyles becomes the realm of relations of power, territorialities and conflicts.

\section{Conservation and new ruralities in Europe}

The European context provides many examples through which to test the impact that pro-rural migrations have on conservation-targeted areas. The sheer importance that conservation policies have gained in Europe in recent decades correlates with the intensity in which pro-rural population movements have occurred. Since the 1960s, a growing number of people from urban areas have been moving into the countryside in search of an alternative life. By doing so, they have transformed rural destinations, both materially and symbolically (Nogué 1988; Silva and Figueredo 2013). Of particular interest are the expectations and motivations behind this population movement, and particularly the attraction felt for protected areas (Prados-Velasco 2006).

These pro-rural migrations chime with different issues of territorial reintegration and land-use reorganization across the continent (Green 2005; Vaccaro and Beltran 2008). For example, in countries like Spain and Portugal the establishment of new NPAs in the last quarter of a century has paralleled the promotion of new economic practices, mainly ecotourism. This corresponds to the European Union's aim to promote the growth of a service economy within peripheral areas, replacing customary farming and fishing practices whose reliance on subsidies make them clearly deficient within a globalized economy (Coca 2008; Figueredo 2008; Gonzalez 1993). 
Some scholars have applied ideas of state territoriality to the interconnected issues of empowered exurban groups and land-use reorganization that has been taking place in many rural areas in Europe (Vaccaro and Beltran 2008). I assert that this approach becomes even more useful when combined with an idea of territory as an area that, on the ground, is the focus of contentions between different social groups who claim to have preferential rights over local resources (Godelier 1986). This slightly extended approach to the idea of territoriality moves beyond the role of the state, transnational institutions or global economic interests, while allowing us to focus on the different actions that, at a local level, certain groups (the neo-rurals) orchestrate towards the appropriation of a particular territory.

\section{Methodology}

In order to answer the aforementioned questions I did four weeks of fieldwork in spring 2014, extending work that I had already done in 2005-06 and 2007-11. I wanted to analyze how power relations in conservation conflicts work on a day-to-day basis from the point of view of the lifestyle embraced by new, neo-rural inhabitants in Cabo de Gata as well as of the efforts they make to transform this place into a natural idyll. I did eleven semi-structured interviews and multiple participant observations. I used several criteria for the selection of informants: they had to be originally from another region; they must have moved to Cabo de Gata for its natural values; and they should have been living in the area for long enough to witness some of the changes this place has experienced.

Between 2005 and 2011, I studied the political, historical and symbolic dimensions of conservation conflicts in the natural park. I did over one hundred semi-structured interviews and thirteen months of participant observation in order to understand people's position towards conservation policies. I mostly worked with local farmers, fishermen, shepherds and landowners, although I also paid attention to neo-rurals, particularly those working either in ecotourism or as part of the park office and directorate.

I opted for qualitative methods because my intention was to produce a 'thick description' of how different positions towards conservation transpire and are reinforced in practices and events that are closely connected to the everyday life of neo-rural inhabitants. My results come from the analysis of people's discourses and the examination of their social behaviors and relations. I analyzed the different reasons why people moved to this area, why they stayed and the different actions and activities they have engaged with in order to enjoy a new lifestyle and produce and defend an idyllic place to live. I contrasted testimonies with my observations from participant observation. I used my previous knowledge of the area to place their testimonies into perspective.

\section{A natural park in the making}

\section{Context}

1987 is a key date in the recent history of Cabo de Gata, the southern-most eastern region of the Iberian Peninsula. That year this desert coast, restlessly battered by extremely dry weather, was declared a natural park. This was the official response to a demand made over many years by part of the local population, mostly newcomers, with the support of experts and regional ENGOs. For them Cabo de Gata was an unspoiled natural place which deserved legal protection against the threats posed by modernity, industrial forms of production and urban development.

The current landscape shows the outcomes of such a milestone (Figure 2). Nowadays this $495 \mathrm{~km}^{2}$ coastal NPA is known mostly for its landscape of barren plains and hills, where only those plants and animals ecologically adapted to desert conditions grow in the wild. Fields of wheat and barley and rearing goat and sheep herds surround scattered small villages of just a few hundred inhabitants. Well-kept footpaths, curvy roads and a few vantage points serve the thriving ecotourism industry, which is currently the most important economic activity in the park. The protected marine area, which comprises almost a quarter of the park, hosts a rich and diverse shallow water ecosystem, which local fishermen exploit and whose singularity attracts both tourists and scientists.

Meanwhile, the park's surroundings have taken quite a different path in recent decades. Confined within an area of intense agricultural production, the park borders on thousands of plastic poly-tunnels. 
Underneath them, fruits and vegetables of all kinds are produced all year round at an industrial scale for exportation to the rest of Europe. The region is nicknamed the sea of plastic since it is saturated with these poly-tunnels. Furthermore, in recent decades it has also been cornered by mass tourism and urban resorts, which have spread from neighboring areas and reached the park's limits. It is thanks to the establishment of the natural park that Cabo de Gata evaded a similar fate. But why and how did this happen?

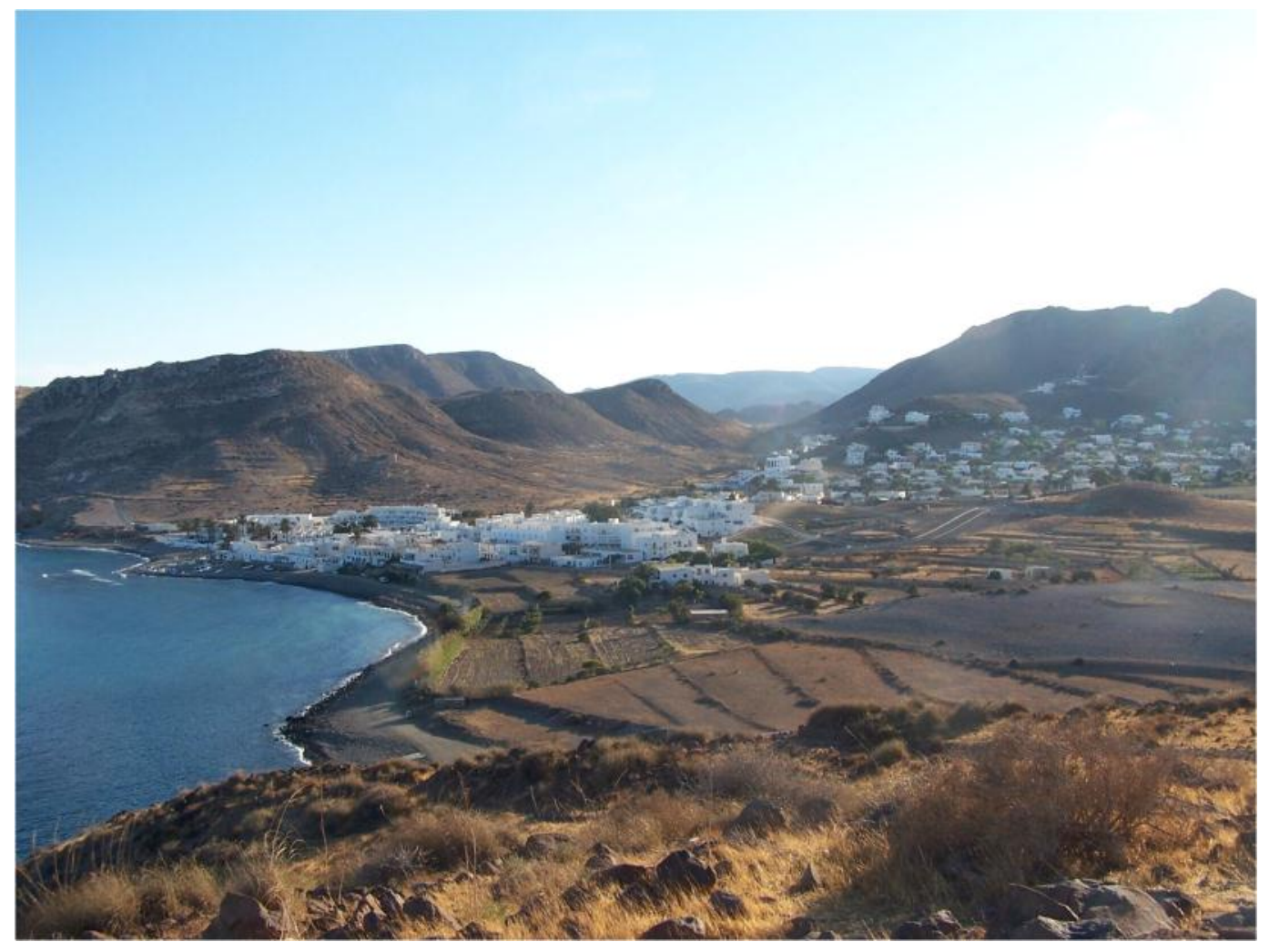

Figure 2: Coastal town in Cabo de Gata (Las Negras). Author: Jose A Cortes-Vazquez.

\section{Constructing a natural idyll}

Despite the symbolism of 1987, the beginning of the story of conservation in this region dates back to the 1960s and 1970s, right after the first neo-rurals started to settle in the area. But the reasons that enticed this pro-rural population movement go even further back, well into the socioeconomic crisis that devastated the region during the early twentieth century. At the beginning of the $20^{\text {th }}$ century, issues of soil erosion and resource misuse, combined with the enclosure of common lands and the ending of mining and export activities, were driving the area into a deep recession. For many years famine and poverty expanded, forcing many people to migrate to urban areas in Spain and elsewhere in Europe. By the 1950s the area had lost most of its inhabitants and workforce, leaving behind abandoned farmsteads and decaying villages. ${ }^{5}$ However, almost overlapping this outward population movement, the area also witnessed the arrival of new people. Inspired by post-1968 ideologies, a growing number of pro-rural migrants set eyes on Cabo de Gata.

Some of these newcomers were just vacationers, but others had long-term plans to stay in the area. They were in the lookout for suitable places to realize their dreams of a life closer to nature. Despite their diverse nationalities (Spanish, French, British, Swiss, Swedish, Dutch, German) and professions (writers,

\footnotetext{
${ }^{5}$ Between 1900 and 1970 population level decreased a striking 38 per cent. This trend changed from the 1980s onwards. The number of people living in Cabo de Gata has doubled since then (from 2,700 to around 5,700) (Source: Andalusia Statistic Institute. http://www.juntadeandalucia.es/institutodeestadisticaycartografia. Last access: July 2011).
} 
musicians, craft workers, teachers, architects, photographers, journalists, civil servants, scientists and pensioners), they shared a common urban and educated background and identified themselves mostly with leftist, liberal and/or bohemian ideologies. Upon arrival, they interpreted the area in a radically different way to that of marginality, poverty and famine. The abandoned farming lands, derelict farmsteads and decaying villages became symbols of an idyll where nature had endured destruction (Figure 3). Take the following quote as an example:

We came here with some friends for the first time. We arrived here by chance, because we were staying in Mojacar [a town a few kilometers to the North], spending a few days on the beach, doing some hiking, enjoying the sea... One day we decided to go for a drive to the South. And that's how I arrived for the first time to 'El Playazo de Rodalquilar' [one of the most famous beaches in the park, near the town of Rodalquilar]. It was shocking. I was shocked to see such an unspoiled place. El Playazo shocked me and so did all the landscape in Rodalquilar and its surroundings. The little road we were taking, so little and narrow, so old... And Rodalquilar, whose streets were unpaved, all made of dirt and sand. We were shocked by the fact of having discovered such a wild place, with such few people, so clean... (Female, originally from Spain) ${ }^{6}$

The strong attraction felt for this area motivated these newcomers to settle in. Yet other more prosaic matters also helped, including affordable housing prices, which had been driven down by outmigration, as well as beneficial currency exchange rates for those coming from abroad. Word of mouth spread quickly among friends, relatives and acquaintances and in just one decade there were hundreds of neo-rurals living in Cabo de Gata. Some worked in small tourist initiatives; others commuted from urban areas nearby. A few of them were artists (painters, photographers, writers), who transformed the area into a workplace and a source of inspiration. Some others only stayed for a few months and worked elsewhere for the rest of the year. For all of them, this place fulfilled their expectations of a truly natural space, hence providing a great opportunity to start a new life they had dreamed:

The first time that I came here was in 1971. I came with my partner, who had already visited the area a year before and who had already fell in love with this place. She told me: I know a place you will love. So we came here and I discovered it and honestly: we both loved it! Think about this: we spent the whole summer camping on the beach and we barely saw anybody for a whole month! Well, a pair of fishermen, some people from a nearby town... There was no tourism back in those days. [...] This was simply mind-blowing for someone who was looking for a place like this, a place to retire, a place where we could have the whole beach for ourselves... [...] And when we came back ten years later with the plan to stay we saw again all these particularities. [...] Because this is exactly what we were looking for: a place without urban developments... just what we couldn't stand in France: lots of cars, lots of civilization, lots of progress... We were just looking for the opposite. (Male, originally from France)

\section{Troubles in paradise}

The road to make this place a home was going to be full of potholes. It did not take too long before these neo-rurals saw their idyll threatened. As mentioned before, the 1970s and early 1980s also witnessed the striking success of intensive greenhouse agriculture and mass tourism in neighboring areas. ${ }^{7}$ Propelled by

\footnotetext{
${ }^{6}$ To facilitate reading, this and the other quotes in the article have been directly translated from Spanish into English by the author. In an effort to reproduce the original narratives, grammar mistakes have been left uncorrected. All names and sensitive information have been removed to preserve anonymity.

${ }^{7}$ According to Hernández (1987), between 1968 and 1984, the total surface area of poly-tunnels jumped from 30 hectares to nearly 11,500 within Almeria Province, where Cabo de Gata is located. It started in rural Campo de Dalías, on the west side of the Province and expanded to the east into areas like Cabo de Gata. By 1984, there was a combined total of 2,153
} 
government support, this success quickly changed many people's perceptions of the barren lands of Cabo de Gata. There were good new opportunities for business, and many were resolved to capitalize on them. This 'gold rush' adopted many forms. Local councils were reserving large estates near the coast for urban and tourism developments; coastal roads were planned and their construction initiated to connect these projected urban centers; local and foreign investors were buying land; migrants were returning with the intention of profiting from their old properties; new poly-tunnels were built and new wells dug (Figure $4 \mathrm{a} \& \mathrm{~b}$ ).

These events alarmed the neo-rural population. They felt compelled to halt the expansion of hotel resorts and poly-tunnels so that the place remained wild, unspoiled and natural. Meanwhile, pre-existent relationships, newly founded friendships and casual encounters were forging new social circles among neorurals in Cabo de Gata. These new bonds provided the infrastructure for the organization of meetings and discussions about the threats to their idyll, and also led to the formation of pro-conservation committees. They orchestrated demonstrations and published exposés in newspapers, asking the government to take action. The newcomers even wrote a pro-conservation manifesto, which was then handed out to politicians in Europe. $^{8}$

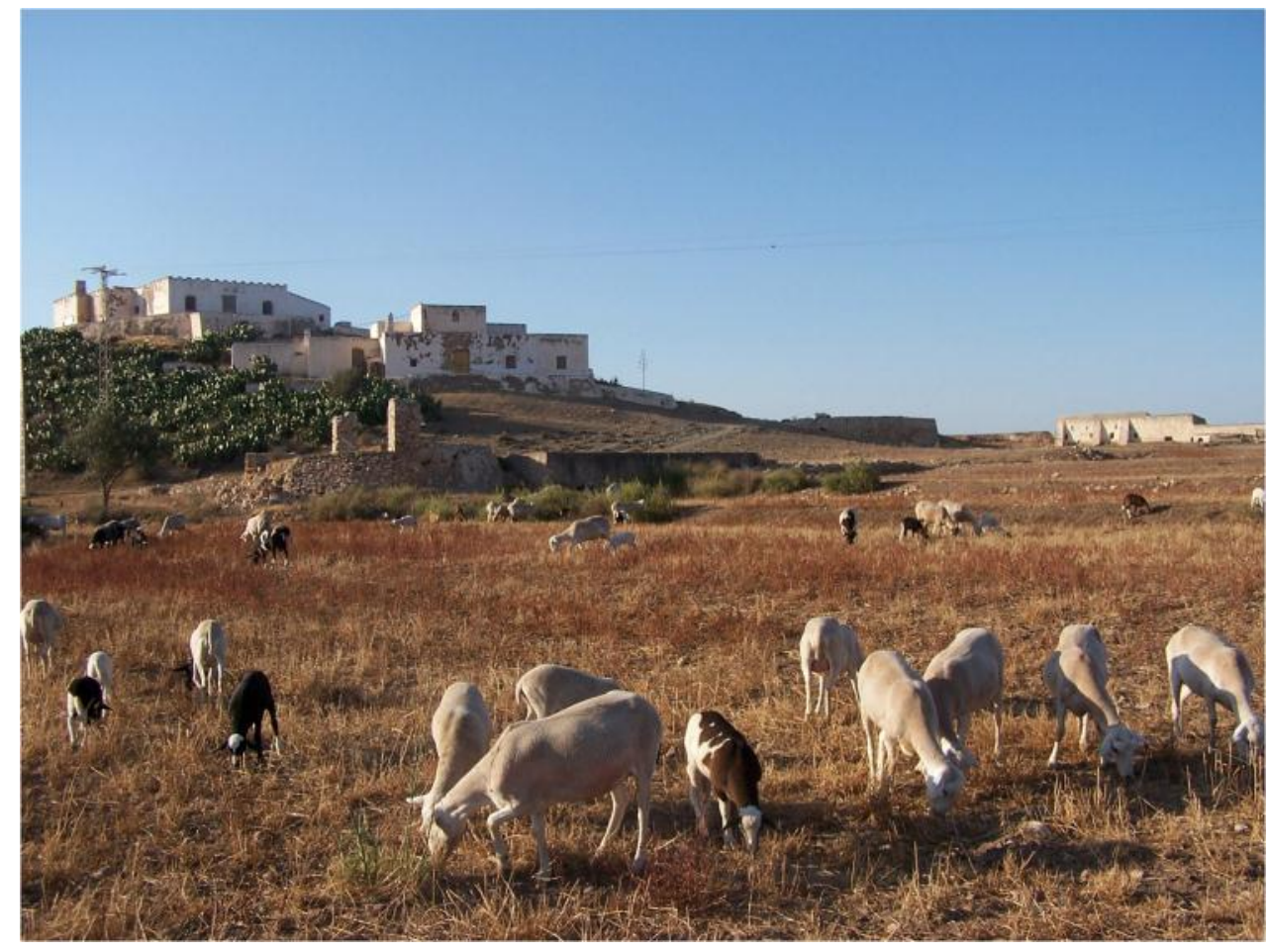

Figure 3: Farmlands in Cabo de Gata (Fernan Perez). Author: Jose A Cortes-Vazquez.

As the time passed and the neo-rural population in Cabo de Gata grew in number, their demands also gained strength. Alongside these struggles, new frontlines emerged as they began to realize that their idyll was far from perfect. There was a lack of potable water, inexistent or deficient garbage collection and disposal, and continued power cuts. Led by neo-rurals, neighbors associations formed in different villages to voice these concerns. Activism prompted slow but continued improvements in infrastructure, services and facilities, moving Cabo de Gata closer to urban and modern living standards.

Very soon their claims received valuable aid, primarily from regional ENGOs (e.g. Grupo Ecologista Mediterraneo) and groups of experts and scientists with research interests in the area's exceptional ecology

hectares of irrigated agriculture in the areas surrounding Cabo de Gata, of which 1,016 hectares were in poly-tunnels. By 2008, 2,085 hectares were dedicated to tomato production in poly-tunnels (Statistics Institute of Andalusia 2013).

${ }^{8}$ A very detailed and rich description of these process and initiatives can be found in Quero (2012), where some of the protagonists of this story explain how they experienced it. 
and geology. However, the decisive backing came from the state. Spain's 'greening' had begun in the 1970s and intensified over the 1980s. ${ }^{9}$ It was critical to the establishment of the Cabo de Gata-Níjar Natural Park in 1987. With this public endorsement of the neo-rurals' demands came an official recognition of the natural values in Cabo de Gata (see more in Cortes-Vazquez 2014). From then onwards, neo-rurals could count on a powerful political actor to defend their interests and concerns: the park office. Formed mostly of outsider experts and bureaucrats, park officials embodied the role of the state ${ }^{10}$ and were granted the power to regulate and manage resource access in a territory where $80 \%$ of the land was privately owned, although only a small percentage by neo-rural inhabitants.
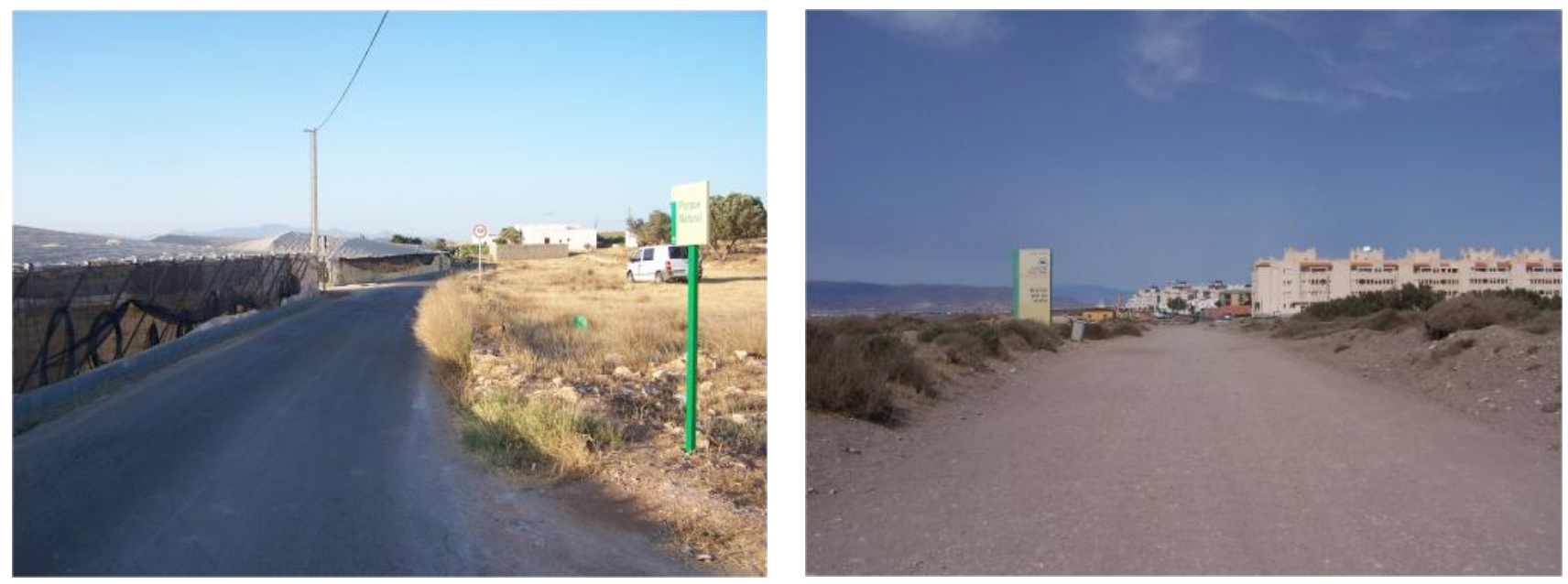

Figure 4 a: Poly-tunnels besides the park (Nijar). Figure 4 b: Hotels next to the park limit (Almeria). Author: Jose A Cortes-Vazquez.

The park instigated new regulations, generating conflicts and contestation. A ban on intensive polytunnel agriculture and further urban development inside the park boundaries triggered bitter confrontations between farmers, developers, landowners and conservation supporters. Limitations placed on other farming, grazing and fishing activities led to a growth in active park opponents (see more in Cortes-Vazquez 2012; Cortes-Vazquez and Zedalis 2013; Valcuende et al. 2011).

Acts of resistance and contestation took many forms. Poly-tunnels were established illegally, new hotels built in forbidden locations, protected areas were plowed and harvested, and fishing restrictions ignored. ${ }^{11}$ All of these acts encountered the strong opposition of neo-rural inhabitants. In many cases they were the ones reporting them to the authorities. Sometimes they went to the media or the courts. Such was their involvement, that during the 1990s they decided to form the ENGO Amigos del Parque Natural (Friends of the Natural Park), which is still a powerful conservation stakeholder in Cabo de Gata. Despite the

\footnotetext{
${ }^{9}$ This greening tried to leave behind the environmentally exploitative policies introduced in Spain during the early Franco dictatorship and to converge with European norms. The result was a proliferation of new Protected Areas during the 1980s and 1990s. In the Region of Andalusia alone, where Cabo de Gata is located, the new NPAs soon covered almost a quarter of the territory. There was an important role played by scientists and experts, as many of them were assigned to investigate and inform the selection of those areas with high ecological values (Mulero 2002).

${ }^{10}$ A clarification is needed at this point. In this article, I am using the notion of state as a synonym for public administration. However, in Spain, it is the multiple regional governments who regulate the establishment, government and management of natural parks, unlike other forms of nature protection. Although Spain is not a federal country, there are disputes between central and regional governments that make state relations problematic. Despite this, I have opted for using 'state' to facilitate links to the literature on state territoriality and conservation, as referenced in previous sections.

${ }^{11}$ Further evidences of these actions can be found in news articles: "La Junta teme el daño irreversible de los invernaderos en Cabo de Gata", El País 2/8/1998; "Medio Ambiente rechaza los cultivos en Cabo de Gata", El País 8/10/1999; "El Algarrobico, 25 años atrás", El Mundo 10/112009; "Building blight on Spanish coastline", The Guardian 7/7/2006; "Costas turn back tide by blowing up a new hotel", The Times 12/5/2006.
} 
paramount role of the park office, at a civil society level neo-rurals have been an extraordinarily important part in the defense of conservation over these past decades. In fact, the story of conservation in this place cannot be wholly understood without them. Take the following example:

You know what? It's the duty of park rangers to report any illegal action. However, in most cases, they merely take note of the infraction and then come to us [the members of the local ENGO] so that it is us who report them, with the excuse that they can't do much. It is us who usually do this as an ENGO. And what is worse is that they even don't do this job properly! Look, we've spotted out forty illegal poly-tunnels here. And the rangers only three! And they don't want to admit that because it would be like admitting they are not doing their job properly! (Male, originally from Spain)

How is the defense of certain ecological and aesthetic values, and a particular lifestyle, embedded within these conservation conflicts? I will depict the lifestyles of these people and their actions to create and defend their natural idyll. My aim is to show that neo-rurals' day-to-day practices and lifestyles are directly linked to expressions of identity and territoriality, and it is at this level that conservation conflicts are subtly manifested. $^{12}$

\section{Vida Natural: lifestyles and rules for inhabiting the idyll}

I borrow the title Vida Natural (Natural Life) from a section of the magazine El Eco del Parque: a newsletter on issues related to Cabo de Gata, published every three months and edited by Amigos del Parque. The Vida Natural section features articles on activities that the authors consider relevant to a natural lifestyle: alternative medicine, meditation and therapies, organic and vegetarian products, applying Buddhist principles to approach life, and enjoying outdoor activities like hiking, to mention only a few. There are also discussions on ecologism, de-growth and transition movements, and cooperation and barter networks. As acknowledged in one of the articles, the "...aim is to provide a means to make our lifestyle be coherent with our environmental concerns" (Eco del Parque, 2003, vol. 31).

This Natural Life section is an expression not only of the kind of lifestyle that neo-rurals seek in Cabo de Gata but also of a set of non-official rules to become 'proper' park inhabitants. Analyzing this is important because, rather than a simple act of physical relocation, pro-rural migrations are a process of constructing an idyll (Halfacree 2013). As mentioned in the previous section, expectations of a life closer to nature and tradition weighted significantly in their decision to leave their home cities and move to this place. ${ }^{13}$ This new life hinges on ideas of what is 'proper' and 'improper.' Their natural idyll is meant to be full with untouched natural values; although it can also accommodate traditional inhabitants and small communities. The way they seek to engage with nature is mostly contemplative, unlike transformative production-driven approaches (Ruiz-Ballesteros et al. 2009). ${ }^{14}$

We will see in what follows how these ideals ${ }^{15}$ combine with other kinds of expectations ingrained in the particular ethos of neo-rurals, while driving the actions taken in the process of idyll construction. Enacting a particular lifestyle, engaging with like-minded people, establishing new relationships, defining a common identity and constructing a new community are essential steps in the production and appropriation of a new place to live, a new territory (Halfacree and Rivera 2011). One of the main outcomes of such

\footnotetext{
${ }^{12}$ I purposely leave aside native inhabitants and other groups because they exceed the scope and limits of this article. For a synthetic analysis of the links between native peoples' identity and their opposition to conservation initiatives, see Cortes and Zedalis (2013). A more detailed and thorough description can be found in Cortes-Vazquez (2012).

${ }^{13}$ The French novelist Michel Houellebecq published a non-academic book in 2005 titled The possibility of an island, in which there is a very interesting description of the expectations of the neo-rural community living in Cabo de Gata.

${ }^{14}$ As analyzed elsewhere (Santamarina 2009; West et al. 2006) these notions rely on modern ideas of nature and the Western nature/society dualism (Descola 2005; Latour 1993). Hence the contemplative approach and the emphasis on values not directly linked to human actions.

${ }^{15}$ A thorough description of the emotional and experiential importance of these ideals can be found in Milton's idea of sentient ecology (2002), referring to the affective relation with nature that is formative in modern environmentalism. For lack of space, I leave an analysis of environmentalist values to a future occasion.
} 
process is that they end up transforming and re-structuring the physical characteristics and social milieu of such places of destination. I will show now the actions carried out by neo-rurals vis-à-vis the search of a Natural Life in Cabo de Gata.

\section{Projecting a new life, enacting a new lifestyle}

As newcomers, finding a way of making a living that is coherent with their expectations of an alternative life has been one of the biggest challenges that neo-rurals admit to having faced after moving to this NPA. The tourism industry has been one of the most frequently embraced alternatives: it is seasonal, which means that there are plenty of opportunities for leisure during the low season, it involves being in touch with people also interested in the natural and cultural values of the area and it provides a mean of living without ruining the local environment. Farms and houses have been transformed into hotels and apartments. Tourist services of all kinds are on offer: guided routes, scuba diving lessons, bike hire services, souvenir shops, groceries, restaurants and pubs. Other people have reconciled a life in the park with a job elsewhere, by commuting, being away part of the week or working from home. A few have found in the park a perfect work environment for activities unrelated to tourism, like painting and writing.

Those that have successfully dealt with this challenge take every opportunity to express their satisfaction and sense of fulfillment. Their new life allows them to enjoy what attracted them to the area, even if for work reasons this is only possible during certain parts of the day or parts of the year: The joy of sitting by the sea everyday, the feeling of being close to nature, the privilege of quiet morning or evening strolls in a healthy environment, the possibility of cultivating ones' own food, the chance to raise their children in a safer and intimate environment and so forth. Take the following quote as an example:

People think we [neo-rurals] are here on permanent holidays. But that isn't true. That isn't going to be your life if you decide to move here. What living here allows you is that after work, instead of going home or to the bar, you can go to the beach with your children. That is quality of life! Also, for me the landscape has an incredible influence in my wellbeing. I walk up there, to that vantage point, and I gaze at the landscape and I melt down... Just a walk up those hills comforts me. But you have to strive to do this, you have to find a house and a way to make a living. (Female, originally from Germany)

The establishment of new relationships and friendships with likeminded people is another big challenge that neo-rurals admit to have faced since moving to the area. Everyday needs have provided a good platform to forge new social bonds. This includes informal exchanges of gifts and favors between neighbors; baby, pet and house sitting; sharing food and leftovers and giving rides. Furthermore, other more sophisticated prerequisites for the satisfaction of their shared, educated, urban taste - in the Bourdieusian sense - have also served as a recurrent excuse to cultivate new social engagements and collaborations. For example, their ingrained predisposition to be on the lookout for certain cultural and leisure activities have frequently motivated the co-operative organization of film festivals, art events and evening courses, such as yoga, meditation, foreign languages or painting (Figure $5 \mathrm{a} \& \mathrm{~b}$ ).

Organizing these activities has sometimes been difficult. They have frequently required long periods of campaigning against what they consider a serious lack of suitable infrastructure (theatres, cinemas, venues, seminar rooms). A good example of this is the community house built in Rodalquilar in 2007. For decades, neo-rurals from this old mining village have been trying to find a space where they could carry out collective activities. They set eyes on the building where the mine workers' union used to be located, to discover that the estate had been illegally appropriated by an individual. A long legal battle led by the Rodalquilar Neighbor Association (RNA) - mostly formed of neo-rurals - ended with ownership of the estate being handed to the local council. The council, at the request of the RNA, restored the building and converted it into a community house. It soon became the main venue for many new activities, the majority of them organized by neo-rurals: yoga, pilates, English classes, and painting, to name but a few. Seeking a larger degree of independence in the organization of events, courses and workshops, the RNA convinced the council to transfer the management of the house to the local community. 
Related examples are the re-enactment or invention of rituals and festivals. Neo-rurals noticed soon after they moved to Cabo de Gata that the social decomposition the area suffered in precedent decades had also caused the disappearance of most festivities. In the last two decades, they have worked towards the organization of new festivals around a myriad of new topics and subject themes that not only accommodate their own personal requirements (for example, availability of those that work in tourism) but also facilitate the integration of people from different backgrounds and sensitivities (for example, avoiding religious topics or animal torture). And all this without diminishing the power of these events in the symbolic structuring and control of local society. Take for example the recently created festival El Desembarco Pirata (The Pirate Landing) in San José village:

Something in which I have participated a lot it's a kind of town fair... a new one, not the one in August, when everybody is working [in tourism]. We have organized our own festival in March. It's The Pirate Landing. I play a soldier. It's a re-creation of a pirate landing in times of Carlos the $5^{\text {th }}$, when the people here fought against pirates from the North of Africa, defending their coast. It's a tourist attraction but mostly a celebration day for the town, when we give awards to those nominated as the most and least friendly neighbor, for example. (Female, originally from Spain)

Activism has been another strategy to seek collaborations and create community among neo-rurals as well as also a way to vindicate a distinct lifestyle. It has been particularly intense in two fields: the protection of the natural values of Cabo de Gata and the improvement of facilities linked to everyday needs, like sanitation and transport. Neo-rurals have a significant track record of lobbying and campaigning to preserve the environmental quality, aesthetic beauty and ecological values of the region. They not only instigated and were key stakeholders in the establishment of the natural park during the 1980s, but have held a proactive attitude ever since. Expressions of this commitment are the periodic organization of rubbish collection days on watercourses and pocket beaches. Other examples include a restlessly vigilant attitude against activities that they consider that could threaten the park's values. An iconic specimen is the war they initiated against the illegal construction of a hotel in a hill near San José, one of the biggest villages in the park. Such was the immersion of some neo-rurals in this process that, once the legal battle was won and the hotel demolished, the vantage point constructed as part of the restoration plan was named after one of the leading activists.
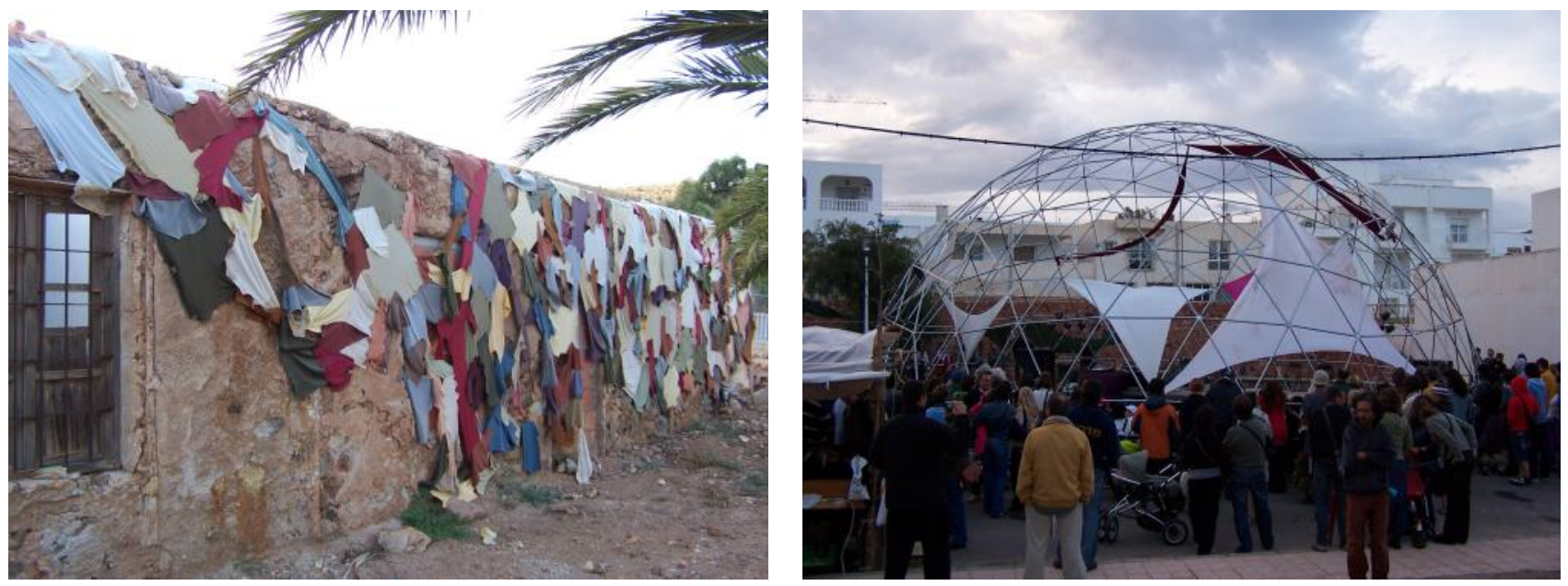

Figure 5 a: Land art in an art festival organized by neo-rurals (Rodalquilar). Figure 5 b: Circus at a street festival organized by neo-rurals (Las Negras). Author: Jose A Cortes-Vazquez. 
Regarding the second field of activism, neo-rurals also have a long track record of initiating improvements to the infrastructure and living conditions in the park. Instances of their demands in the last three decades include improvements in water quality, creation of sewage treatment plants, removal of telecommunication aerials located next to schools, installation of Internet broadband, regular rubbish collection, introduction of recycling bins, a more reliable electricity supply and daily school buses. The ways these demands have been brought up are diverse, including demonstrations and signed petitions.

These actions are essential steps towards the construction of a place that lives up not only to the neorurals' expectations but also to their living standards and taste. Furthermore, we also need to appreciate the critical part that they play in the construction of new relationships and the distribution and negotiation of new roles. This double character shows the close connections of these actions with processes of community formation. They are important for bridging the gap opened by the frequent mismatch between expectations of a Natural Life and the less satisfying routine of living in a remote area (Halfacree and Silva 2011). Take the following two quotes as examples:

As soon as I arrived here, I started to get in touch with people. That is how we founded El Eco del Parque; that is how we formed Amigos del Parque; that is how we founded the neighbor association in Rodalquilar... All that allowed me to meet other people and establish new friendships. (Female, originally from Spain)

Imagine that you arrive here with your child and you want to go to the playground and this is in poor conditions. That is an example of why we wanted to change things. Because if one is used to go to the playground, not only for your children but also because it's a place to meet people... if you are not used to go knock at other people's door, what can you and your children do? The native kids, they go around looking for the others, go to others' places... But we are not used to that and there was no place where our children could get together and play in this village. If there is a new kid in town, they could be forever alone. And the same for the parents, they won't have the chance to meet people and do what normal neighbors do. (Female, originally from Spain)

Such is the importance of engaging with processes of community formation, that they have even motivated neo-rurals to give up some of the key expectations that attracted them to Cabo de Gata. I found good examples in the testimony of those who had initially moved into abandoned farmsteads or very remote villages within the park, seeking tranquility, freedom, independence and a closer relationship with nature. The impairments that such levels of isolation generate when it comes to establishing and consolidating new social relations has been critical for them to relocate to larger villages. This is reinforced by the fact that neorurals have worked hard to make these towns progressively more attractive for their specific tastes and more suitable for their own needs.

Once I got pregnant I realized that the idyllic life I had planned with a baby in the middle of the park was going to be more comfortable and idyllic if I could go to the beach on foot pushing the baby buggy... if I had the pharmacy and kid's school nearby, if there was a playground where my child could play with other children... and if in the event that I have an accident I am able to shout for help and be heard... (Female, originally from Spain)

\section{Natural lifestyle and discipline: defending a new territory}

The actions and efforts described in the previous section also hint at further difficulties other than the lack of infrastructure and social bonds. The plethora of different backgrounds that characterize these people has also posed new challenges. When neo-rurals moved to the area, most were sharing what Bourdieu would call a similar cultural capital (relatively similar artistic taste, levels of education, interests) as well as common concerns (pursuing a natural life). Upon arrival, they thought this would be enough to forge relations with like-minded people. However, many soon realized that there were other issues at stake e.g. levels of involvement, age, language and an interest in socializing. Over years, these different issues have prompted 
the creation of many sub-groups among neo-rurals, arranged by nationalities, levels of activism or even attitudes towards nightlife. In light of this diversity, the involvement in activities conducive to a natural lifestyle has had not only the function of facilitating relationships: they have also regulated them. The guidelines provided in the Vida Natural section, with which I opened this part of the article, are clear examples.

Nonetheless, it is in the relationship with other social groups where the regulatory function of this lifestyle is most clearly visible. This is the case of the interactions between neo-rurals and the native or local inhabitants. These interactions have been thoroughly ambiguous over the last few decades. Disagreements regarding lifestyles are used by neo-rurals as key reasons to explain why they tend to forge better and closer relationships among themselves. These disagreements include the locals' perceived disregard for neo-rural tastes in the arts, social activities and conventions, and even the dress codes. The disaffection is mutual, and there is also criticism of native economic priorities, social conventions and even dialects and accents:

I have a very good relation with my neighbors. Though it's true that those who I consider my friends are none from this place. But I'm not the only one in that position: everybody here does the same. Why? Well one thing is that we have all arrived from elsewhere, so we are all in the same position. Maybe that's why there is more empathy among foreigners. In other cases it can be because of intellectual empathy, mostly because of the kind of life you lived before, the kind of friends you've made, the places you've visited... (Male, originally from Spain)

This neo-rural/native division contrasts profoundly with neo-rurals' asserted interest in local lives. As aforementioned, part of the expectations that initially attracted these newcomers to the area was the possibility of escaping the consumerist, alienating lifestyles that they associate with life in a modern and urban society. They sought to engage with a traditional, pre-modern and local community via interactions with the native locals and attachment to the land. Take the following quote as an example:

I was born in 1963. This means I was educated a liberal and I have always been free to do what I pleased... and that was completely the opposite of what I found here. And yet it was here where I found for the first time women that were truly interesting! Imagine this: It was 1986 [when I arrived here], I had no money, yet I had no problem in using the washing machine every day. And my female neighbors, even with more economic means than me, went everyday to the public well to get water and washed their clothes by hand at the public washing place. Why? To save water! That is when I started to learn how to live here. (Female, originally from Spain)

Despite this type of initial interest, the locals have rarely lived up to neo-rurals' expectations of traditional inhabitants. Many elements of friction have made their relationships difficult. Neo-rural environmental activism supported restrictions on farming, grazing and fishing. As analyzed elsewhere, these changes in land use following the introduction of conservation policies have had a direct impact on native s' livelihoods (Cortes-Vazquez 2012; Cortes-Vazquez and Zedalis 2013; Valcuende et al. 2011). The resulting animosity by locals towards conservation is approached by neo-rurals as either their incapability to appreciate the park's natural values, a lack of environmental education, or a selfish and materialist attitude towards nature (Cortes-Vazquez 2012).

The tensions between these two groups surpass conservation conflicts and different tastes. They are acute in perceptions of different lifestyles. For instance, the search for a neo-rural livelihood that increases opportunities for leisure, by working part-time or in a seasonal activity like tourism, is deemed characteristic of lazy, indulgent people. The independence and privacy that neo-rurals try to safeguard vis-à-vis their sexuality, friendships or the education that they give to their children make them to be reluctant to share certain information with the natives. In turn, the natives find this suspicious: they consider it as a rejection when local norms are ignored, including the gossiping and intrusion in private life typical of small rural communities. 
Further evidence can be found in the social initiatives organized by neo-rurals. Festivals or cultural activities have usually drawn little attention from the native locals. Neo-rurals argue that the locals are more interested in traditional religious festivals and feasts, and not the artistic and other culture and leisure activities that they organize (Figure $6 \mathrm{a}$ and b). A consequence of these divisions is that many social events tend to appear in duplicate: one for each of these two groups.
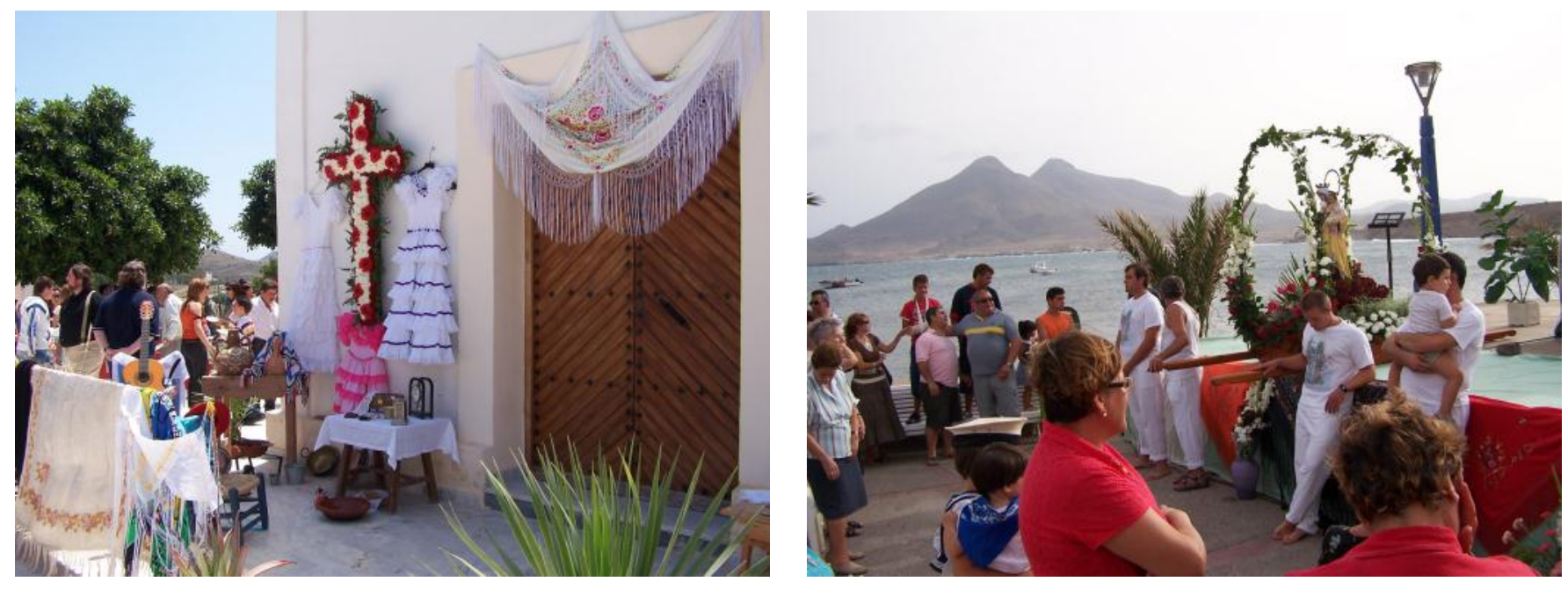

Figure 6 a and b: Religious festivals organized by the local population (Pozo de los Frailes and La Isleta). Author: Jose A Cortes-Vazquez.

I hinted in the introductory section of this article that the political dimension of this division, and the connections with conservation conflicts, is more evident when we approach them from a Bourdieusian frame. As with studies on urban gentrification, in the process of deploying cultural capital (lifestyles, tastes, mannerism, education) to achieve distinction, new social groups end up transforming space (their neighborhood, their house) so that it adjusts to their particular habitus (see for example Bridge 2001, 2006). We can read the actions that neo-rurals have taken in order to re-shape Cabo de Gata in a similar way, transforming it to chime with the living standards in which their lifestyle is ingrained. And this involves not only working towards the improvements of infrastructure and services, but also towards the re-structuring of the social milieu.

Neo-rurals tend to complain that their initiatives always struggle in a society structured around an endemic and historically inherited patronage system. A successful initiative needs the approval of local figures of importance, like local caciques and big landowners. Neo-rurals approach the low participation of native locals in the activities that they propose as attempts to reproduce clientelistic relations of power, while maintaining the status quo. For neo-rurals, the native locals always neglect or ignore these actions regardless of the very basic needs that they target: organizing demonstrations to ask for better water quality, handing out a petition for a school bus service for all the towns in the park, etcetera. Even when their claims are successful, neo-rurals feel disgruntled with the small recognition that the native locals usually grant to their efforts:

One of the big problems we have is the lack of proper infrastructures; there are no public transports. When I came here there was no school bus. Kids were sent to a boarding school for the whole week. And I didn't want that: have I come to live in a paradise to end up sending my child to a boarding school? But the problem was that we all had to drive our kids to school everyday and it was far away. So I went to talk to government officials to ask for a school bus and I was told to get a signed petition from other local residents. So off I went to find people... It turned out that there were enough people interested in this and we got the school bus. This is 
why associations are important, because then you have a voice that can be heard by the authorities. And that is something the native locals never understand, they wouldn't say boo to a goose [...]. When we have suggested organizing in associations they always reacted: no, we will ask the park officials to do that for us, full stop! And all they do is just tell those working for the park: hey, tell your chief there are potholes on the road... (Female, originally from Germany)

This is a good example of the connection between the new lifestyles that neo-rurals are seeking to introduce in their lives by moving to Cabo de Gata and the kind of social fabric that this tends to generate. In their effort to construct a place suitable for their new lives, they not only encounter opposition by people that yearn for other kinds of lifestyle; they also seek ways to channel their own concerns without necessarily abiding with pre-established structures of power. Instead of resorting to asking favors from local caciques, a practice still common in rural Spain, they organize associations and demonstrations, in a more urban fashion. This shows two different procedures and two different ways of navigating the social environment, which for some people is a rather visible issue. Not surprisingly many neo-rurals justify the native locals as unsupportive of their own initiatives because "the natives like other things" and "do things differently."

Bourdieu argued that it is our own habitus, as the embodiment of a particular cultural capital, which provides us the skills and dispositions that are fundamental to knowing how to maneuver within a particular social environment. He also suggested that those that bring into play these skills and dispositions do so unconsciously and in a non-discursive manner. In situations like Cabo de Gata, where there are clear differences between two particular habitus, the capacity to voice particular concerns and interfere in the process of decision-making depends a great deal on a re-shaping of the social milieu and the conventions that govern it. Each group not only tries to transform space to accord with lifestyle norms, but they also adjust the social fabric to their own specific social dispositions. This may yield them an advantage over the other in their capacity to influence the government.

A natural life, if defined as the representation of a particular lifestyle that is inseparable from the neorural habitus, is something more than enforcement of a hegemonic ideology. It should not try to reinforce neo-rural status and lifestyle to the determent of longstanding native ideologies, or by diminishing their understanding of place and environment. ${ }^{16}$ The neo-rural habitus, by not trying to convince, seduce, control or govern others in a Foucauldian sense, but by just imposing itself upon others, reveals its true nature: it aims to shape the social fabric in Cabo de Gata so that neo-rurals can defend their right to govern. This is entangled with their efforts to defend their own attitudes towards life, taste, clothing or mannerisms, in other words, their cultural capital and, by extension, the habitus that results. The same applies to their criticism and rejection of the tastes and lifestyles of others. The overarching goal is to defend a particular shared identity that, as Bourdieu would say, cultural capital contributes to creating. And, because every notion of community implies a definition of modes, forms and rights with respect to land appropriation (Godelier 1986), the actions taken by neo-rurals to create and defend an idyll in which to enact a very specific lifestyle, as described in previous section, prove to be active forms of territoriality. This is an extremely subtle but effective form of exerting power; a power that is at the margins of the state, which is not articulated in a discourse, which escapes the normal proceedings of ideology or the 'conduct of conduct.' A form of power that is rather ubiquitous and at the same time underhand, and that expresses itself in apparently anodyne events and everyday practices.

In short, the definition of a common, natural lifestyle is paramount to understanding the social fabric of Cabo de Gata, for several reasons. First of all, it has permitted neo-rurals to overcome cultural and social differences as a group whose members come from many different regions and backgrounds. The idea of natural life as lifestyle acts as the catalyst for the union of people and the emergence of a new identity and, consequently, a new community.

\footnotetext{
${ }^{16}$ There are still circumstances in which neo-rurals seek to convince or impose their environmental discourses upon the native locals (see Valcuende et al. 2011 for Cabo de Gata or Escobar 1996 for a more general examination of this phenomenon). It just means that this was not the case for the issues analyzed in this article.
} 
Furthermore, this lifestyle also permits to identify 'others.' To understand this, we need to remember that the new park inhabitants structure their lives around a set of goals inspired by the aim of experiencing an alternative lifestyle to what they left behind. They fled from cities and industrial areas that they deemed unhealthy and alienating. In the less populated countryside they sought a much more relaxed and intimate life. They searched a less polluted environment, with plenty of green spaces to carry out outdoor activities, from extreme sports to evening strolls. They believed that a life in a small community would provide them a safer and friendlier environment to raise their kids. Those that contradict these aspirations end up being classified as 'others', distinct from "us aspirational nature dwellers." This has a disciplinary dimension because it implies that those 'others' are not suitable for the idyllic surroundings, and even do not deserve to have access to land and govern the environment. The following quote shows this rather clearly:

Imagine a place as beautiful as San José. It was so weird to see that, next to an amazing house, there was a garbage dump where the very owner of that adjacent house was dropping the rubbish. First a house, next a garbage dump and then another house... That was outrageous! Why couldn't we connect with the locals? Because they lived that way, not looking after the environment, not taking care of your immediate surroundings. So what we did was to get into the neighbors association. It was funny to see that almost everybody in the association was from abroad... There were very few natives. And it was a very active time because we fought to bring here what should be normal in every town: a proper rubbish disposal and collection system. (Male, originally from France)

\section{Conclusions}

In this article, my goal has been to demonstrate that the conservation policies that regulate resource and land use at the Cabo de Gata-Níjar Natural Park, as well as the institutions and techniques through which these policies are enforced, are by no means the only way that environmental governance is exerted. I contend that neo-rural inhabitants and their everyday practices play also a key role in disputes over the preservation/exploitation of natural resources. To show this, I have tried to demonstrate that conservation conflicts are developed and widened partly because of the multiple daily actions of neo-rural inhabitants; including personal relations, different forms of activism and the organization and participation in rituals and social events.

I have dedicated most of this article to the ethnographic analysis of the everyday practices that neorural inhabitants in Cabo de Gata carry out in order to construct and defend an idyll wherein to live a 'natural life.' I have argued that the enactment of a particular lifestyle as part of that process has a disciplinary character. We can approach this character from two different sides. Firstly, as a particular habitus. In Cabo de Gata the neo-rural habitus organizes practices and the perception of practices, creating a social division. This is evident when we look at the kind of participants of most of the activities that define the neo-rural lifestyle: who takes part in demonstrations against new hotels and new poly-tunnels? Who takes yoga classes? Who leads the celebration of new festivals? And who participates in new art events like a play performed by children in English? The disciplinary character of these dividing practices emerges from their role in processes of identity and community formation. They are the grounds that neo-rurals use to differentiate between those people that can inhabit their idyll and those that cannot. A natural lifestyle, as an identity-defining factor, encompasses ideas of the 'self' and of 'others.' This self-other division is political because it is the key to justifying and legitimizing forms of territorial appropriation and uneven distribution of resource and land rights.

Secondly, we can also see neo-rurals' lifestyle as a strategy used to bypass established and customary structures of power in Cabo de Gata. By defending this lifestyle, neo-rurals seek to transform the social milieu so that they can make the most of the specific social dispositions that come with their urban, educated and skilled habitus. The main goal is to have an advantage over other social groups seeking influence in decision-making. As such, neo-rurals can benefit from their cultural capital (e.g. high education, expert knowledge) and capacity to connect with global discourses (e.g. environmentalism), new institutions (park office) and supra-local lobbies (ENGOs), while counterbalancing assets such as landownership or 
clientelistic relations, which are the strong points of those groups with whom neo-rurals compete for territorial control.

These two disciplinary dimensions of the lifestyles and everyday practices that neo-rurals activate are essential for understanding the current social fabric in Cabo de Gata as well as the conflicts that have emerged since the introduction of conservation policies. By focusing on the experiences of people moving to a new place and looking for a new life, the negotiations they go through in that process, the activities carried out to pursue that goal, and the lifestyles they deploy, it has been my goal to explore how power in the conservation field is also subtly exerted through a myriad social interactions and relations. This is how a particular art event can be seen as a source of social divisions and conflicts.

As outlined in the introduction, the contribution that this article makes to the political ecology of nature conservation is both practical and theoretical. It is practical because it extends one of the most common points made in the critical analysis of conservation. This insists in the need to change attitudes among institutions, policy makers and ENGOs regarding conservation and its impacts on people and the environment. However, such changes would be incomplete if we ignore the fact that, in some cases like Cabo de Gata, power is not only exerted by these institutions and agents with the support of some local groups, but also that power is deployed in personal relationships between local groups that compete for the same resources.

Theoretically, the contribution of this article to the field of conservation and political ecology derives from the fact that it challenges the idea that power in conservation relies mostly on the role of institutions, states, markets, ENGOs, bureaucracies and technologies of government. Instead, with an approach to power as distributed and exerted in a myriad of social relations I demonstrate that there is room for a rethinking of the conservation model in those areas strongly affected by neo-rural movements, including the European Union. This rethinking, however, exceeds the scope of this article. My intention has been to suggest some of the elements that could be essential parts of that model.

\section{Bibliography}

Adams, W.M. 2004. Against extinction: the story of conservation. London: Earthscan.

Adams, W.M. and J. Hutton. 2007. People, parks and poverty: political ecology and biodiversity conservation. Conservation and Society 5(2): 147-183.

Agrawal, A. 2005. Environmentality: community, intimate government, and the making of environmental subjects in Kumaon, India. Current Anthropology 46 (2): 161-190.

Anderson, D.G. and E. Berglund. 2003. (eds.) Ethnographies of conservation: environmentalism and the distribution of privilege. New York: Berghahn Books.

Apostodopoulou, E. and W.M. Adams. 2014. Neoliberal capitalism and conservation in the post-crisis era: the dialectics of "green" and "un-green" grabbing in Greece and the UK. Antipode (published online)

Arsel, M. and B. Büscher. 2012. Nature ${ }^{\text {TM }}$ Inc.: changes and continuities in neoliberal conservation and market-based environmental policy. Development and Change 43(1): 53-78.

Berkes, F. 2004. Rethinking community-based conservation. Conservation Biology 18(3): 621-630.

Berkes, F. 2009. Community conserved areas: policy issues in historic and contemporary context. Conservation Letters 2(1): 20-25.

Blaikie, P.M.and H. Brookfield. 1987. Land degradation and society. London \& New York: Methuen and Co. Ltd.

Bourdieu, P. 1977. Outline of a theory of practice. Cambridge: Cambridge University Press.

Bourdieu, P. 1979. La distinction: critique sociale du jugement. Paris: Les edition de Minuit. summary

Bridge, G. 2001. Bourdieu, rational action and the time-space strategy of gentrification. Transactions of the Institute of British Geographers 26: 205-216.

Bridge, G. 2006. Perspectives on cultural capital and the neighbourhood. Urban Studies 43(4):719-730.

Brockington, D. 2002. Fortress conservation: the preservation of the Mkomazi Game Reserve, Tanzania. Oxford: James Currey. 
Brockington, D. 2014. Celebrity advocacy and international development. Oxon and New York: Routledge.

Brockington, D. and R. Duffy. 2010. Capitalism and conservation. the production and reproduction of biodiversity conservation. Antipode 42(3): 469-84.

Brockington, D., R. Duffy and J. Igoe. 2008. Nature unbound: conservation, capitalism and the future of protected areas. London: Earthscan.

Bryant, R. L. 1992. Political ecology. an emerging research agenda in Third-World studies. Political Geography 11 (1): 12-36.

Büscher, B., S. Sullivan, K. Neves, J. Igoe and D. Brockington. 2012. Towards a synthesized critique of neoliberal biodiversity conservation. Capitalism Nature Socialism 23(2): 4-30.

Caideux, K.V. and P. Hurley. 2009. Amenity migration, exurbia, and emerging rural landscapes: global natural amenity as place and as process. GeoJournal 76(4): 297-302.

Chatty, D. and M. Colchester. 2002. (eds.) Conservation and mobile indigenous peoples: displacement, forced settlement and sustainable development. Oxford \& New York: Berghahn Press.

Coca, A. 2008. Los camperos. Territorios, usos sociales y percepciones en un espacio natural andaluz. Sevilla: Fundación Blas Infante.

Corson, C. 2011. Territorialization, enclosure, and neoliberalism: non-state influence in struggles over Madagascar's forests. The Journal of Peasant Studies 38(4): 703-726.

Cortes-Vazquez, J. 2012. Naturalezas en conflicto: conservación ambiental y enfrentamiento social en el Parque Natural Cabo de Gata-Níjar. Valencia: Germania \& AVA.

Cortes-Vazquez, J. 2014. Protected areas, conservation stakeholders and the naturalization of Southern Europe. Forum for Development Studies 41(2): 183-205.

Cortes-Vazquez, J. and M. Zedalis. 2013. Identity and native species conservation: similar historical ecologies from Idaho to Spain. Human Ecology 41(6): 937-945.

Cronon, W. 1995. (ed.) Uncommon ground: rethinking the human place in nature. New York \& London: W.W. Norton \& Company.

Descola, P. 2005. Par-delà nature et culture. Paris: Gallimard.

Duffy, R. 2008. Neoliberalising nature: global networks and ecotourism development in Madagascar. Journal of Sustainable Tourism 16(3): 327-345.

Escobar, A. 1996. Constructing nature: elements for a poststructural political ecology. In R. Peet and M.J. Watts (eds.) Liberation ecologies: environment, development, social movements. London \& New York: Routledge. Pp46-68.

Escobar, A. 1998. Whose knowledge, whose nature? biodiversity, conservation, and the political ecology of social movements. Journal of Political Ecology 5: 53-82.

Escobar, A. 1999. After Nature: steps to an anti-essentialist political ecology. Current Anthropology 40(1): 130.

Escobar, A. 2000. El lugar de la naturaleza y la naturaleza del lugar: Globalización o posdesarrollo. In A. Viola (ed.) Antropología del desarrollo: teorías y estudios etnográficos de América Latina. Barcelona: Paidós. Pp113-143.

Fairhead, J. and M. Leach. 1996. Misreading the African landscape: society and ecology in a forest-savanna mosaic. Cambridge: Cambridge University Press.

Fairhead, J. and M. Leach. 2003. Science, society and power: environmental knowledge and policy in West Africa and the Caribbean. Cambridge: Cambridge University Press.

Ferguson, J. 1990. The anti-politics machine: "development," depoliticization and bureaucratic power in Lesotho. Cambridge: Cambridge University Press.

Figueiredo, E. 2008. Imagine there's no rural: the transformation of rural spaces into places of nature conservation in Portugal. European Urban and Regional Studies 15: 159-171.

Fletcher, R. 2010. Neoliberal environmentality: towards a poststructuralist political ecology of the conservation debate. Conservation and Society 8(3): 171-181. 
Foucault, M. 2003. "Society must be defended": lectures at the Collège de France, 1975-1976. New York: Picador.

Godelier, M. 1986. The mental and the material: thought, economy, and society. London: Verso.

Gonzalez, I. 1993. (ed.) Parques Naturales Andaluces. Conservación y cultura. Sevilla: Junta de Andalucía.

Gray, L.C. 2002. Environmental policy, land rights, and conflict: rethinking community natural resource management programs in Burkina Faso. Environment and Planning D: Society and Space 20(2): 167182.

Green, S. 2005. From hostile backwater to natural wilderness: on the relocation of 'nature' in Epirus, Northwestern Greece. Conservation and Society 3(2): 436-460.

Guha, R. 2000. Environmentalism: a global history. Oxford: Oxford University Press.

Guha, R. and J. Martinez-Alier. 1997. Varieties of environmentalism: essays North and South. London: Earthscan.

Halfacree, K. 2013. Running wild in the country? Mobilising rural in-migration. In L. Silva and E. Figuereido (eds.) Shaping rural areas in Europe. New York \& London: Springer. Pp11-24.

Halfacree, K. and M.J. Rivera. 2011. Moving to the countryside ... and staying: lives beyond representations. Sociologia Ruralis 52 (1): 92-114.

Hernández, M.C. 1987. La agricultura intensiva del Campo de Dalías. Paralelo 37 10: 133-140.

Holmes, G. 2009. Global conservation and local resistance: power and protected areas in the Dominican Republic. PhD Dissertation. Manchester, UK: University of Manchester.

Holmes, G. 2014. Defining the forest, defending the forest: political ecology, territoriality, and resistance to a protected area in the Dominican Republic. Geoforum 53:1-10

Igoe, J. 2004. Conservation and globalization: a study of national parks and indigenous communities from East Africa to South Dakota. Belmont, CA: Wadsworth / Thompson Learning.

Igoe, J., K. Neves, and D. Brockington. 2010. A spectacular eco-tour around the historic bloc: theorising the convergence of biodiversity conservation and capitalist expansion. Antipode 42(3): 486-512.

Latour, B. 1993. We have never been modern. London: Prentice Hall.

Mackenzie, A.F.D. 2006. 'S Lein Fhein am Fearam (The land is ours): re-claiming land, re-creating community, North Harris, Outer Hebrides, Scotland. Environment and Planning D: Society and Space 24(4): 577-598.

Mahon, M., F. Fahy and M. Ó Cinnéide. 2012. The significance of quality of life and sustainability at the urban-rural fringe in the making of place-based community. GeoJournal 77(2): 265-278.

Mels, T. 2002. Nature, home and scenery: the official spatialities of Swedish national parks. Environment and Planning D: Society and Space 20 (2): 135-154.

Milton, K. 2002. Loving nature: towards an ecology of emotion. London \& New York: Routledge.

Moreno-Navarro, I. 1996. Los rituales festivos religiosos andaluces en la contemporaneidad. Actas de las I jornadas de religiosidad popular. Almeria: Instituto de Estudios Almerienses. Pp: 319-332.

Mulero, A. 2002. La protección de espacios naturales en España: antecedentes, contrastes territoriales, conflictos y perspectivas. Madrid: Mundi-Prensa.

Neves, K. and J. Igoe. 2012. Uneven development and accumulation by dispossession in nature conservation: comparing recent trends in the Azores and Tanzania. Tijdschrift voor economische en sociale geografie 103(2): 164-179.

Nogue, J. 1988. El fenómeno neorural. Agricultura y Sociedad 47: 145-175.

Peet, R., P. Robbins and M.J. Watts (eds.) 2010. Global political ecology. London and New York: Routledge.

Peluso, N.L. 1995. Whose woods are these? Counter-mapping forest territories in Kalimantan, Indonesia. Antipode 27 (4): 383-406.

Peluso, N. and C. Lund. 2011. New frontiers of land control. The Journal of Peasant Studies 38 (4): 667-681.

Pepper, D. 1996. Modern environmentalism: an introduction. London and New York: Routledge. 
Prados-Velasco, M.J. 2006. Los Parques Naturales como factor de atracción de la población. Cuadernos Geográficos 38: 87-110.

Quero, J. M. 2012. (ed.). Reflexiones en el Parque Natural Cabo de Gata-Níjar. Almería: Junta de Andalucía.

Redford, K. 2011. Misreading the conservation landscape. Oryx 45(3): 324-330.

Robbins, P. 2004. Political ecology. Oxford: Blackwell Publishing.

Ruiz-Ballesteros, E., J.M. Valcuende, V. Quintero, J.A. Cortes-Vazquez and E. Rubio. 2009. Naturalising the environment: perceptual frames, sense, and resistance. Journal of Material Culture 14(2): 147-167.

Ruiz-Ballesteros, E. 2009. Agua Blanca. Comunidad y turismo en el Pacífico ecuatorial. Quito:Abya-yala.

Santamarina, B. 2009. De parques y naturalezas. Enunciados, cimientos y dispositivos. Revista de Dialectología y Tradiciones Populares 64 (1): 297-324.

Silva, L. and E. Figuereido (eds.). 2013. Shaping rural areas in Europe. New York \& London: Springer.

Sletto, B. 2002. Boundary making and regional identities in a globalized environment rebordering the Nariva Swamp, Trinidad. Environment and Planning D: Society and Space 20 (2):183-208.

Sullivan, S. 2006. The elephant in the room? Problematising 'new' (neoliberal) biodiversity conservation. Forum for Development Studies 33(1): 105-135.

Sullivan, S. 2013. Banking Nature? The spectacular financialisation of environmental conservation. Antipode 45(1): 198-217. draft

Vaccaro, I. 2005. Property mosaic and state-making: governmentality, expropriation and conservation in the Pyrenees. Journal of Ecological Anthropology 9(1): 4-19.

Vaccaro, I. and O. Beltran. 2008. Consumiendo espacio, naturaleza y cultura. Cuestiones patrimoniales de la hipermodernidad. In O. Beltran, J.J. Pascual and I. Vaccaro (eds.) Patrimonialización de la naturaleza. El marco social de las políticas ambientales. Donosti: Ankulegi. Pp45-64.

Vaccaro, I., O. Beltran, and P.A. Paquet. 2013. Political ecology and conservation policies: some theoretical genealogies. Journal of Political Ecology 20: 255-272.

Valcuende, J.M., V. Quintero and J. Cortes-Vazquez. 2011. Discursive natures in protected areas. Journal of Iberoamerican Anthropology 6 (1): 27-56.

Vaschetto, A. 2006. La migración utópica: recorridos migratorios, fronteras e identidades de los europeos en el pueblo de Tezpoztlán, México. Maguaré 20: 99-124.

West, P., J. Igoe and D. Brockington. 2006. Parks and people: the social impact of protected areas. Annual Review of Anthropology 35: 251-277.

Zimmerer, K.S. 1996. Discourses on soil loss in Bolivia: sustainability and the search for socioenvironmental 'middle ground.' In R. Peet and M.J. Watts (eds.) Liberation ecologies: environment, development, social movements. London \& New York: Routledge. Pp110-124. 